\title{
Modeling the formation of an industrial enterprise operating income
}

\author{
T.N. Myznikova ${ }^{1, *}$, E.V. Bunova ${ }^{1}$, and E.N. Yaroslavova ${ }^{1}$ \\ ${ }^{1}$ South Ural State University, Chelyabinsk, Russia
}

\begin{abstract}
The developed economic and mathematical model of the industrial enterprise's operating income formation allows to reveal cause-and-effect relations and to form a mechanism of influence of initial (base) indicators on the studied index (operating income of a business entity). The model is based on the regression analysis. The base indicators forming the economic and mathematical model are grouped into two blocks: production assets and labour resources influencing the enterprise's financial standing, namely, its operating income. This grouping allows to evaluate efficiency of the influence of production assets and labour resources on the enterprise's potential at taking of justified management decisions. The mechanism of the enterprise's industrial potential management modeling includes analysis of base indicators (factors) of each of the considered blocks. With the help of the developed economic and mathematical model, by setting base values of factors, we can consider their influence on the resulting index - operating income of any business entity; and vice versa, by setting the resulting index we can analyze the influence of base indices for efficient management of the industrial enterprise's operating income.
\end{abstract}

\section{Introduction}

Efficiency of a business entity is predetermined by the condition and quantitative composition of its production resources, their quality use and timely renovation. In this regard, almost all industrial enterprises lack floating assets not only for renovation and updating of their production assets, but also for carrying out their current activities. According to the authors [1], most heads of Russian enterprises use this factor for explanation of financial instability of their productions. At the same time, they do not account for duplication of functionalities in different divisions, which leads to disbalance of cash flows and deficiency of resources for re-equipment [2]. It is rather difficult to take a management decision on composition, amount, terms of replacement and sources of financing of production assets renovation. In this regard, the enterprise's fixed assets are subject to moral wear, apart from physical wear, which affects competitive ability of production. Consequently, in order to increase financial stability of enterprises and their competitive power, enterprises need a mechanism of their production potential management. Modeling of the industrial enterprise's production potential management process has become particularly important at the present time characterized by negative factors affecting socioeconomic development of Russia in conditions of the unstable global political and economic situation.

\section{Urgency and scholarly Importance}

Scholarly importance of the considered issue is confirmed by an extensive discussion in the economic circles devoted to types, forms and principles of modeling the enterprise's potential management processes, including the innovative one.

Issues of sources of financing and financial planning at the enterprise are closely linked with studying of lines of expenditure, which often requires specification of the object of study. It becomes particularly important at modeling of the financial management process, which is confirmed by the authors of the research [3].

N.A. Saltykov [4] considers theoretical aspects of "modeling" category and identifies elements, which, in his opinion, must form this model.

Classification and evaluation of the industrial enterprise's economic potential is presented in the work $[5,6]$. The author analyzes potential threats to functioning of the industrial enterprise at taking of erroneous decisions in the course of the industrial enterprise's economic potential management.

In this regard, several scientists $[5,7,8]$ are inclined to consider the enterprise's potential from the perspective of innovative development, which is certainly expedient. However, innovations - in the wording of Azgaldov G.G. and Kostin A.V. [9] are defined as a process of introducing novelties accompanied by certain conditions: availability of documents of title for the novelty; production of relevant goods protected with these documents; the goods must be

\footnotetext{
*Corresponding author: myznikovatn@susu.ru
} 
compatible at the global level, as well as ensure a higher effect than the previously manufactured good.

Based on this assumption, we come to the conclusion that the authors, upon consideration of issues on modeling of the enterprise's innovative potential management, do not describe the innovative but the production potential. At the same time, there are not enough mathematical models able to solve online problems on resource sufficiency formation for the industrial enterprise, or the models are too complicated for practical application.

In the context of the considered problem, the work [10] is worth noticing. However, the author considers the entire set of business processes in one information collection, while local tasks - ensuring of the production resource renovation - are more important for enterprises.

A more detailed evaluation in the course of the enterprise's potential modeling is presented in the work [7]. The author analyzes in detail consequences of resource potential use for the enterprise but considers only one segment - labour resources, which does not reflect the entire scope of the enterprise's production resources.

In the work [11] the author sets a mathematical dependency between the enterprise's financial flows and remuneration of labour. However, in the context of the presented model it is impossible to distinguish connection between the labour potential and the financial result.

Production potential is deeper studied and classified in the work [12]. The author discloses the mechanism for evaluation of the enterprise's resource potential use, formulates its dynamic normal to determine composition and efficiency of use and sets the enterprise's operating efficiency depending on each of the elements. However, limitation of the author's model lies in the fact that in the research the focus is made on sectorial specificity, which reduces the range of application of the models.

In the context of the studied problem be believe it is interesting to overview the enterprise's resource potential modeling process in tasks of project management by means of stochastic dynamic programming. [13]. In this case, the author considers potential development of the enterprise simultaneously by means of extensive (quantitative) and intensive (qualitative) factors.

As it is shown in the works $[14,15]$, intensive factors are able to increase efficiency of enterprises.

Results of the conducted research have shown that currently there is no integrated practice applied for analysis of the industrial enterprise's operating income.

Thus, urgency of this research is preconditioned, firstly, by the necessity to supplement methods of scientific cognition of the industrial enterprise's operating income formation and management in the strategic aspect. Secondly, it is preconditioned by the necessity to create a practical set tools for calculation and analysis of the industrial enterprise's operating income, which would ensure stable financial standing of the enterprise and its competitive power both in the short- and long-run.

\section{Problem statement}

It is impossible to build an efficient system of production company management in ever-changing conditions of its functioning based only on intuition. An efficient management system must be based on building and application of the economic and mathematical model allowing to outline interconnections between the disturbing influence and the response of the economic system thereto. As it is described in the work [16], it is necessary to develop an adequate model with outlining of interconnections between the disturbing influence and the response of the economic system thereto and then, if such situation occurs in practice, use such management action, which leads to the set management objective.

This model is aimed at setting of cause-and-effect decreases of production effectiveness and use of production assets and finding of an optimal solution for elimination thereof.

\section{Building of the industrial enterprise's operating income formation model}

Let us consider stages of building the economic and mathematical model of the industrial enterprise's operating income analysis:

Stage 1. Determination of the indicator, which reflects the enterprise's strategic development. As such indicator let us choose indicator "operating income" defined as income earned as a result of the company's core activity, i.e. reflecting income from production activity and ignoring the enterprise's financial activity. This indicator is a base strategic indicator of production efficiency, which positive value allows the enterprise not only to have financial stability but also to perform planning and implementation of innovative projects at the enterprise.

Thus, let us take indicator "operating income" as the resulting indicator of the economic and mathematical model.

Stage 2. Selection of generalized (concerning processing industry) indicators influencing the enterprise's income.

As the analysis of industrial enterprises' operating efficiency has shown, the key problem of most business entities is decline in productivity of production assets and low level of renovation of production assets. Consequently, let us take the first group of indicators for analysis - performance indicators reflecting productivity of fixed assets. This group will include basic key indicators, such as index of production, coefficient of fixed assets' renovation, degree of fixed assets' depreciation, availability of fixed assets of gross book value as of the end of the year.

Indicators of the second group - indices of labour efficiency of the industrial enterprise's employees, namely: index of labour productivity, index of capital/labour ratio change, average number of people employed in the economy, also influence the resulting operating income indicator.

In order to describe activity of enterprises from the processing industry we have selected indicators: index of labour productivity (ILP), indices of capital/labour ratio 
change (ICLRC), indices of production (IP), coefficients of fixed assets' renovation (CFAR), degree of fixed assets' depreciation as of the end of the year in percentage (DFAD), average annual number of people employed in the economy (AAN), availability of fixed assets of gross book value as of the end of the year (FA), operating income (OI). The background data are taken from electronic resource http://www.gks.ru and presented in "Tab. 1" and in "Fig. 1".

Table 1. Dynamics of the studied indicators of enterprises from the processing industry (data on the Russian Federation).

\begin{tabular}{|c|c|c|c|c|c|c|c|}
\hline \multirow[b]{2}{*}{ Year } & \multicolumn{7}{|c|}{ Indicator name } \\
\hline & $I L P$ & ICLRC,\% & $\begin{array}{l}\text { IP, } \% \\
\text { versus } \\
\text { the } \\
\text { previous } \\
\text { year }\end{array}$ & $C F A R$ & $\underset{\%}{D F A D}$ & $\begin{array}{c}\text { AAN, } \\
\text { mln. } \\
\text { people }\end{array}$ & $\begin{array}{c}F A, \\
\text { mlrd. } \\
\text { rub. }\end{array}$ \\
\hline 2005 & 103.7 & 103.7 & 106.0 & 5.4 & 47.1 & 11506 & 1440 \\
\hline 2006 & 101.9 & 101.9 & 108.5 & 5.8 & 46.8 & 11359 & 1575 \\
\hline 2007 & 97.5 & 97.5 & 108.4 & 6.4 & 46 & 11368 & 1963 \\
\hline 2008 & 102.1 & 102.1 & 102.6 & 6.9 & 45.6 & 11191 & 2260 \\
\hline 2009 & 96.3 & 96.3 & 95.9 & 6.2 & 45.7 & 10401 & 2567 \\
\hline 2010 & 103.0 & 103.0 & 105.2 & 5.9 & 46.1 & 10292 & 2860 \\
\hline 2011 & 99.8 & 99.8 & 105.6 & 6.4 & 46.7 & 10281 & 3127 \\
\hline 2012 & 100.8 & 100.8 & 103.1 & 6.5 & 46.8 & 10170 & 3335 \\
\hline 2013 & 99.2 & 99.2 & 105.5 & 6.9 & 46.6 & 10173 & 3672 \\
\hline 2014 & 100.7 & 100.7 & 104.3 & 6.9 & 46.9 & 10176 & 3910 \\
\hline
\end{tabular}

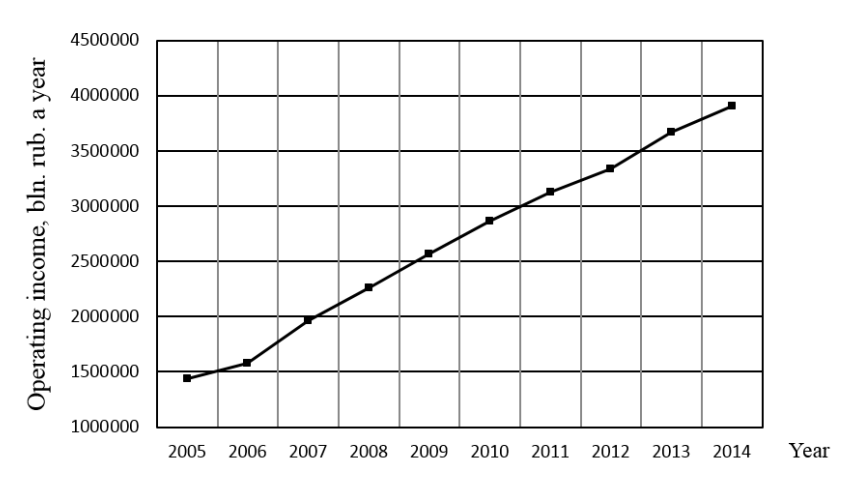

Fig. 1. Operating income of enterprises the processing industry caption.

Stage 3. Building of the economic and mathematical model reflecting general tendencies of functioning of enterprises from the processing industry.

Currently for building of economic and mathematical models the method of principal components $[17,18]$ and the linear regression analysis [19-21] have become widespread. Eigen value problems can be solved by the linear regression analysis, which allows to analyze indicators by means of the cause-and-effect mechanism of initial (base) indicators' influence on the index under study. Besides, the researches conducted by the authors in the work [20] have shown that regression models can be used for building of adequate economic and mathematical models: "in $70 \%$ of cases regression analysis models correctly classify the enterprise's overall financial standing, in $85 \%$ of cases - liquidity and business activity, in $80 \%$ - financial stability, in $100 \%$ - return on investments".

Therefore, at building of the economic and mathematical model of the industrial enterprise's operating income analysis let us use the linear regression analysis.

"Tab. 2" contains parameters (coefficients) of regression by the seven studied factors (indicators) as a result of application of the linear regression analysis based on the data presented in "Tab. 1".

Table 2. Estimated values of coefficients.

\begin{tabular}{|l|c|c|c|}
\hline \multirow{2}{*}{$\begin{array}{c}\text { Factor } \\
\text { (variable) }\end{array}$} & $\begin{array}{c}\text { Estimated } \\
\text { value }\end{array}$ & Symbol & Indicator name \\
\hline Y result & $-5757,25$ & & Coefficient \\
\hline X 1 & 47,6641 & ILP & $\begin{array}{c}\text { Index of labour } \\
\text { productivity }\end{array}$ \\
\hline X 2 & 220,679 & ICLRC & $\begin{array}{c}\text { Indices of } \\
\text { capital/labour ratio } \\
\text { change, (in \%) }\end{array}$ \\
\hline X 3 & $-0,0024$ & FA & $\begin{array}{c}\text { Availability of fixed } \\
\text { assets of gross book } \\
\text { value as of the end of } \\
\text { the year (mln. rub.) }\end{array}$ \\
\hline X 4 & $-3,43$ & AAN & $\begin{array}{c}\text { Average annual } \\
\text { number of people } \\
\text { employed in the } \\
\text { economy (ths. people) }\end{array}$ \\
\hline X 5 & 158,1 & IP & $\begin{array}{c}\text { Indices of production } \\
\text { (in \% versus the } \\
\text { previous year) }\end{array}$ \\
\hline X 6 & 1548,34 & CFAR & $\begin{array}{c}\text { Coefficients of fixed } \\
\text { assets' renovation }\end{array}$ \\
\hline X 7 & $-79,94$ & DFAD & $\begin{array}{c}\text { Degree of fixed assets' } \\
\text { depreciation as of the } \\
\text { end of the year (in \%) }\end{array}$ \\
\hline
\end{tabular}

So, let us make a generalized economic and mathematical model of the processing enterprise's operating income analysis (1):

$O I=-5757,25+47,66 I L P+220,7 I C L R C-0,0024 F A-$ $3,43 A A N+158,1 I P+1548,34$ CFAR - 79,94 DFAD

The determination coefficient of this model comprises 0,78 , consequently, the model built by means of the linear regression analysis is adequate. Graphical proof of adequacy of the built model is presented in "Fig. 2".

As it is clear from "Fig. 2", over the periods, when the income goes downs, estimated and actual values approach to the maximum extent. It has confirmed adequacy of the model and expediency of its application in conditions of lacking resource potential and financial complications. 


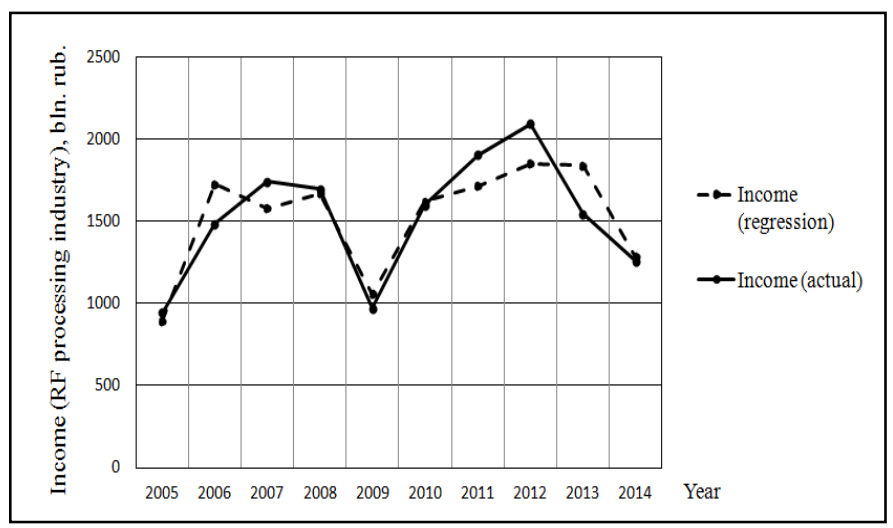

Fig. 2. Dynamics of regression and actual income.

As a result of building the model we can make the following conclusions:

- The coefficient of fixed assets' renovation has the strongest influence on the value of the operating income.

- The index of labour productivity, the index of capital/labour ratio change, the index of production and the coefficient of fixed assets' renovation have a positive influence of the value of the operating income.

- The degree of fixed assets' depreciation, availability of fixed assets of gross book value and the average annual number of people employed in the economy have a negative influence of the value of the operating income.

Stage 4. For building of the operating income management model by means of the industrial enterprise's factor system let us form a system of initial factors influencing the main analytical factors (“Tab. 3").

Table 3. System of Initial Factors Influencing the Main Analytical Factors.

\begin{tabular}{|l|l|}
\hline \multicolumn{1}{|c|}{ Analytical factor } & \multicolumn{1}{c|}{ Initial factors } \\
\hline \multicolumn{1}{|c|}{ Production factors } \\
\hline $\begin{array}{l}\text { Availability of fixed assets } \\
\text { of gross book value, mln. } \\
\text { rub. }\end{array}$ & $\begin{array}{l}\text { Book value of fixed assets as of the end of the } \\
\text { year, mln. rub. (I) }\end{array}$ \\
\hline $\begin{array}{l}\text { Indices of production, in } \\
\% \text { versus the previous year }\end{array}$ & $\begin{array}{l}\text { Amount of equipment, units (Q); coefficient of } \\
\text { equipment loading (K); coefficient of defective } \\
\text { products manufactured at the available } \\
\text { equipment (B). }\end{array}$ \\
\hline $\begin{array}{l}\text { Coefficients of fixed } \\
\text { assets' renovation }\end{array}$ & $\begin{array}{l}\text { Cost of newly commissioned new equipment, } \\
\text { mln. rub. (J) }\end{array}$ \\
\hline $\begin{array}{l}\text { Degree of fixed assets' } \\
\text { depreciation as of the end } \\
\text { of the year, \% }\end{array}$ & $\begin{array}{l}\text { Actual service life of the fixed asset item } \\
\text { versus the regulated value (C) }\end{array}$ \\
\hline $\begin{array}{l}\text { Average annual number of } \\
\text { people employed in the } \\
\text { economy, ths. people }\end{array}$ & $\begin{array}{l}\text { Number of production workers employed at } \\
\text { the enterprise (L) }\end{array}$ \\
\hline $\begin{array}{l}\text { Index of labour } \\
\text { productivity }\end{array}$ & $\begin{array}{l}\text { Labour productivity (P); growth rate of labour } \\
\text { productivity (T); correlation of qualification of } \\
\text { works and workers (G); growth rate of } \\
\text { personnel qualification (L) }\end{array}$ \\
\hline $\begin{array}{l}\text { Indices of capital/labour } \\
\text { ratio change, \% }\end{array}$ & \begin{tabular}{l} 
Capital/labour ratio (F) \\
\hline
\end{tabular}
\end{tabular}

Thus, we have formed a group of initial factors, which can be controlled online by the enterprise management, which must allow the business entity to control the condition of its production assets and to form resources for their renovation and/or updating.

At exercising control we propose to use the processing enterprise's operating income model based on general tendencies of processing enterprise functioning with application of initial factors for each business entity of this field (2):

$$
\begin{aligned}
& O I=-5757,25+47,66 f\left(\begin{array}{ll}
P & G \\
T & L
\end{array}\right)+220,7 F I- \\
& -0,024 I-3,43 L+158,1 f\left(\begin{array}{l}
Q \\
K \\
B
\end{array}\right)+1548,34 J- \\
& -79,94 C
\end{aligned}
$$

Resting on the developed model we can take management decisions aimed at stimulation of priority causes influencing the final result.

Thus, the developed model of operating income formation allows to establish a strategy of the industrial enterprise's asset development.

\section{Conclusions}

Monitoring of scholarly literature corresponding to the research subject allowed to form the most important, according to the authors, set of factors forming the model of the industrial enterprise's operating income management process. In the course of the research the authors have shown that economic and mathematical modeling of the operating income management processes by means of production assets and labour resources is able to increase competitive power, to ensure growth of labour productivity and to achieve the planned financial results. The offered model is a practical set of tools for analysis of the industrial enterprise's operating income.

\section{References}

1. A.L. Shestakov, Standards and Quality, 5, 62-68 (2011)

2. T.B. Krasnenko, T.N. Myznikova, Proc. Modern Society: Scholarly View of the Young, 86-90 (2015)

3. A.V. Pleshakova, T.N. Myznikova, Proc. Modern Society: Scholarly View of the Young, 96-99 (2015)

4. N.A. Saltykov, Bulletin of the Udmurt University: Economics and Law, 2, 64-69 (2012)

5. T.O. Tolstykh, Bulletin of Kursk State Agricultural Academy, 1, 61-64 (2011)

6. B. Manganelli, P. Morano, F. Tajani, Wseas Transactions on Business and Economics, 11, 683-691 (2014) 
7. N.M. Salun, Business Inform, 5, 178-181 (2012)

8. A.G. Khananaev, A.V. Kovalenko, L.N. Zaikina, Scientific journal of the Kuban State Agrarian University, 70(06), 1-14 (2011)

9. G.G. Azgaldov, A.V. Kostin, Economic Strategies, 2, 5460 (2008)

10. P.P. Pereverzev, Proc. Education and Science in Modern Conditions, 208-211 (2015)

11. E.A. Korobkova, Advanced High Technologies, 3, 79-80 (2005)

12. A.V. Goncharuk, Economic Justification of Evaluation of the Mining Enterprise's Resource Potential Use (Ph.D. Dissertation). http://www.dissercat.com /content/ ekonomicheskoe-obosnovanie-otsenki-ispolzovaniyaresursnogo-potentsiala-gornogopredpriyatiy\#ixzz3zwUcqVxx.

13. A.V. Dokuchaev, Mathematical Modeling of Resource Distribution in the Task of Project Management by Means of Stochastic Dynamic Programming (Ph.D. Dissertation, Saratov, 2011)

14. O.G. Turovsts, Organizer of Production, 1, 34-40 (2006)

15. E.O. Plekhova, Economic Analysis: Theory and Practice, 3, 64-67 (2008)

16. T.A. Khudyakova, A.V. Shmidt, Modern Management Technologies, 8(44), 1-6 (2014)

17. V.V. Mokeev, E.V. Bunova, N.A. Krepak, Bulletin of the South Ural State University. Series: Computer Technologies, Management and Radio Electronics, 4, 7381 (2014)

18. O.S. Buslaeva, Problems of Modern Economy, 3, 6-24 (2014)

19. V.V. Mokeev, Economics and Mathematical Methods, 4, 82-90 (2010)

20. I.Ju. Glukhikh, Management Consulting, 3, 185-195 (2011) 